\title{
Non-Implementation Despite Legislation: Lipsky's Theory of Street-Level Bureaucracy and Certain Procedural Criminal Provisions of the Bengal Excise Act, 1909 and the Narcotic Drugs \& Psychotropic Substances Act, 1985
}

\begin{abstract}
Subrata Biswas
Correspondence: Subrata Biswas, Special Excise Commissioner (Enforcement) under Government of West Bengal, India. Formerly, Zonal Director in Narcotics Control Bureau, Govt. of India.
\end{abstract}

Received: November 2, 2020

Accepted: November 27, 2020

Online Published: December 15, 2020

doi:10.11114/ijlpa.v4i1.5106

URL: https://doi.org/10.11114/ijlpa.v4i1.5106

\begin{abstract}
Public policies are reflected in the public domain more by how laws are implemented on the ground than by what their legislative content is. The departures from legislative intent are often scripted by the non-legislative actors at the cutting edge level in public organizations and people outside of the reference frame are often at their wits' end as to why such departures take place at all. This essay takes up two Indian laws - one provincial and the other federal — and relying upon Michael Lipsky's theory of street level bureaucracy, seeks to explore why two critical provisions thereof remained mostly unimplemented right since their legislation. Why do the street level bureaucrats mostly intend to depart from the avowed intent? Do they really stand to gain in such a scenario of non-implementation? If so, how? These questions are discussed in an expanded way in regard to the Bengal Excise Act, 1909 and the Narcotic Drugs \& Psychotropic Substances Act, 1985.
\end{abstract}

Keywords: Street Level Bureaucracy, Lipsky, Non-implementation, Bengal Excise, NDPS Act

\section{Public Policy: Legislation and Implementation}

\subsection{Law and Public Policy}

Laws are enacted in order that certain policy objectives can be achieved in the public domain. Whatever be necessary in order that a system of governance can run smoothly in a specific direction is sought to be put in place by way of legislation enacted by the competent bodies. Thomas Dye had famously said, "Public policy is whatever a government chooses to do or not to do" (Dye, 1972). It is this conscious decision on the part of a government which gets reflected in the form of legislations brought out by the elected officials. Whatever a legislature intends is captured in the form of laws that are born in the hallowed halls of legislature.

And laws are not just about what is what. While the substantive laws spell out the broad dos and don'ts, it is the adjective or procedural laws that provide the mechanism of getting the things done (Note-1). And both these parts do have a substantial role to play in the overall scheme of legislative intent (Note-2). Very often such procedural parts are delineated in the body of subsidiary rules framed by way of delegated legislation by the permanent executive. But most of the special laws do contain a built-in mechanism providing for such procedural bits.

Once policies are formulated, the next phase involves their implementation. Public policy implementation refers to the exercising of a specific policy decision as directed by the law, court, or any administrator's prescriptions (D. Mazmanian, 1983)

It takes two paradigms, bottom-up and top-down. The bottom-up approach holds that public policy implementation process is inseparable from the formulation phase (Matland, 1995) The role of administrators is also considered as critical in the success of the formulation and implementation of the policies from the paradigms of the bottom-up approach. The bottom creates the need for a given policy. The top then responds by creating the policy.

The top-down approach in implementing public policies is rather bureaucratic. This approach suggests that policy formulation and implementation can be separated into two different entities which do not apparently enjoy the same degree of importance, unlike in the bottom-up approach. In the top-down, the 'top' is charged with the so-called noble role 
of making the policy while the 'bottom' is in an apparently mundane charge of implementation. However, public policy experts claim that any degree of success in policy implementation is a function of integration of both the layers including proactive participation of all the stakeholders in the process (B.Milward, 1980)

\subsection{Michael Lipsky \& Street Level Bureaucracy}

Michael Lipsky theorizes how the role of cutting edge officials in their capacity as public service delivery agents in certain areas of governance can impact the degree of policy implementation since translation of such public policy largely hinges upon the knowledge or skill of such officials in regard to implementation of the relevant laws in question or their attitude towards implementation thereof on account of multiple reasons. Michael Lipsky broadly categorizes police officers and other law enforcement officials, judges in the courts of first instance and public lawyers among certain other officials in one expanded bracket and calls them street level bureaucrats and tentatively identifies them as a group in terms of multiple behavioral characteristics. As a group, they are characterized by (i) regular and direct interaction with citizens, or the recipients of government services and (ii) the power to exercise a degree of discretion over the services, benefits and sanctions received by those recipients.

Lipsky then goes on to show how on account of these factors certain laws and rules are very often enforced in a way different from what is devised by the legislature. Laws are after all what capture a public policy in a certain domain and thus, a given public policy is bound to suffer in case some of the provisions of such laws and rules are enacted in a way which marks an obvious departure from the avowed path of legislative intent.

But why do the so-called street level bureaucrats act in the way they act? Do they purposely seek to frustrate the legislative intent? Or do they do it compulsively? If so, what can be the factors behind such behavior? Let us try to understand how Lipsky seeks to theorize the service delivery behavior of such street level bureaucrats and along what lines.

\subsection{Policy Formulation-Implementation Dichotomy}

What the street-level bureaucracy theory majorly seeks to propound, among others, is that the policies of the public agencies employing such bureaucrats get to be largely reflected in what such public servants do or decide in their work. It is chiefly by way of noticing their action on the ground and at the cutting edge level that an ordinary citizen forms an idea in regard to what the government apparently chooses to do or not do. Hardly an uninformed and uninitiated citizen can be in a position to know, far less assess, what approach a so-called government policy document may contain in regard to a specific issue. Of course, one may access such documents online to have an idea in this regard; but then, a man on the street is more interested in what happens in reality rather than what may lie shrouded in official language.

These street-level bureaucrats play a significantly discretionary role as they go about doing their job. The policy framers are in fact not always in a position to shape their actions absolutely in tandem with the terms of the public policy because such bureaucrats are regarded as specialized officials and thus, their discretionary modifications very often acquire some kind of legitimacy within the organizational hierarchy.

Apart from discretion exercised by the street-level bureaucrats, what else assumes importance in regard to such formulation implementation divide is the amount of relative freedom from strict organizational control such officials enjoy. Their work can hardly be reduced to certain set rules and formulae and thus, someone not directly in the know of their work can really be in a position to supervise them effectively. They may even possess varying perspectives from those of their supervisors. Very often, they may also take recourse to such means designed to act as a bulwark against the larger policy expectations. They can go on strike, resort to absenteeism or even adopt a deliberately difficult go-slow attitude. This admixture of discretion and lack of effective control may often lead to situations not even remotely foreseen by the policy framers.

\subsection{The Nature of Stress Confronted by the Street-Level Officials}

But why do the street-level bureaucrats behave in the way they behave? Lipsky lists certain specific factors which he thinks are responsible for this.

\subsubsection{Inadequate Resource}

Human resource happens to be the most important resource for every organization and many such street-level bureaucrats would be found sadly affected by the challenges emerging out of human resource issues. Often, there are too few officials in an agency doing the work of so many and thereby leaving the officials always looking for ways and means to customize the work for their own convenience and often to the detriment of the policy interest. There are cases where officials are ill-equipped from the training point of view and thus, hamstrung in regard to how to get a thing done in accordance with the terms of policy. There are also cases where the officials are badly required to make do with a number of serious deficiencies emerging out of lack of organizational resources. 


\subsubsection{Undefined or Contrary Expectations From Organization}

There are cases where government agencies have undefined goals or such goals which may run contrary to the very objectives the agencies actually exist for. An organization may develop over the years perspectives which appear to stand at variance with the stated policy objectives simply because none really cared about the written words any more. There can be situations where declared public policies may differ from actual agency objectives and it may be completely beside the mark to be trying to look for any correlation between the two.

\subsubsection{Difficulties in Performance Assessment}

Lipsky then goes on to the necessary corollary of such undefined goals inflicting public organizations. Because of the fact of such conflicting expectations from organization, it becomes very difficult to assess the performance of such street-level bureaucrats. Lack of clarity about the organizational goals significantly impairs the prospects of officials' performance assessment. Such lack of clarity also results in more than one course of action actually being permissible or endorsable in a given situation and there may often be an inherent conflict between one such course of action and another. Evidently, performance measurement becomes a veritable problem in such cases and the street-level officials thus often suffer from absence of direction. No wonder, they often conveniently choose the course of self-direction.

\subsubsection{Serving the Captive Clients}

Because of the unique nature of their services, clients hardly change the service-providers because of absence of more than one service-provider against a given service. This monopoly leaves the clients more or less at the mercy of the street-level bureaucrats who in a way takes things largely for granted. They thus find little or no incentives at all in reshaping their own course of action under a given circumstance.

Thus, in fine, going by Lipsky's theory of street-level bureaucracy, such officials are largely found to be working in worrisome situations inflicted by scarcity of resources and a disconcerting lack of clarity in their organizational relevance. A large amount of compulsive discretion at their disposal coupled with a veritable lack of modalities to measure their organizational performance goes to complicate the scenario in a far worse manner. In addition, a disturbing extent of monopoly present in the nature of the services they render towards the clients is what places the challenge of policy implementation more precariously at the mercy of the street-level officials.

\section{Bengal Excise Act, 1909: A Case Study in Divergence Between Word and Action}

\subsection{Bengal Excise Act: Its Policy Objectives}

One of the oldest provincial laws dating back to the days of British Raj, the Bengal Excise Act as is seen now was formulated in 1909 with the stated objective of streamlining all governmental action to be taken in regard to potable alcohol (Note-3). The Constitution of independent India places potable alcohol in the State List as provided in the $7^{\text {th }}$ Schedule in terms of Article 246 and leaves it entirely to the State Government to formulate policies and frame laws and rules in regard to that.

Like in many other States in India, Excise revenue has been one of the most significant sources of revenue for the State of West Bengal. The State is free to impose any amount of excise duties on potable alcohol which is meant to be officially sold within the State (Note-4) and the State Government has all the authority to ban any operations whatsoever in regard to manufacture, export, import, transport, possession and sale of such alcohol or allow them on certain conditions (Note-5). The corollary is that any such alcohol that has been manufactured without authority and thus situated outside of the realm of collectible State revenue is illicit in terms of law and it is a punishable offence to manufacture, sell or transport or even possess such alcohol. In fact, this happens to be a cognizable offence in terms of criminal law and, subject to compliance of certain broad conditions, the empowered officials are free to arrest the offenders without any warrant issued by the Courts (Note-6).

Arrests in criminal law are to be preceded and followed by some necessary formalities. In terms of Sections 41 and 41A of the Criminal Procedure Code, 1973, none may be arrested unless he be reasonably suspected of having been involved in the commission of an offence not to be tried by a Sessions Judge and any of the conditions stipulated vide Section 41 $\mathrm{CrPC}$ be not reasonably satisfied. Arrests within the scope and meaning of BE Act too are guided by the same paraphernalia. However, following any act of arrest, all arrestees are required to be forwarded to the court of a Judicial Magistrate within twenty four hours from such act of arrest vide Section 81 of the Act read with Article 22.

\subsection{What Happens After the Arrestee is Forwarded to the Court?}

The Bengal Excise Act is a special law and thus, like in many other special laws, there is a distinct difference in terms of post detection procedure. The general code of procedure, i.e. CrPC stipulates that right from the first day, i.e. right after the forwarding of the arrestee to the Court, the Judicial Officer is aware of the course of investigation not just for exercising his judicial power in matters relating to applications for bail pressed by the arrestee but also for deciding 
other issues, for example, release of property seized at the time of arrest.

Within the special scheme of things devised by the Bengal Excise Act, the detection of a case is primarily reported to the Collector of Excise under Section 78(1) of the BE Act and he remains the supreme authority throughout the investigation period vide Section 78(2) of the BE Act in regard to questions involving custody or release of any articles seized by the detecting officer. The Collector under Section 74(2) of the BE Act can also drop all the proceedings against the arrestee if investigation undertaken by the empowered officer warrants likewise. However, the case is finally reported to the judicial magistrate under Section 74(4) of the BE Act if the investigation reveals that there is enough evidence to initiate judicial action against him, which may potentially culminate in his conviction.

\subsection{Section 74(4) of Bengal Excise Act: Its Significance Vis-À-Vis Code of Criminial Procedure, 1973}

The Section 74(4) of the BE Act reads: As soon as an investigation by a Collector or by an Excise Officer empowered under Section 73, sub-section (2), has been completed, if it appears that there is sufficient evidence to justify the forwarding of the accused to a Magistrate, the investigating officer, unless he proceeds under sub-section (2) of this section or under Section 65 of this Act, shall submit a report, which shall for the purpose of Section 190 of the Code of Criminal Procedure, 1973 be deemed to be a police report, to a Magistrate having jurisdiction to inquire into or try the case and empowered to take cognizance of offences on police reports.

Several issues emerge out of this text. First, investigation into the commission of offence allegedly committed by the suspect has to be completed by the empowered official. Second, such investigation duly completed would have to point towards prima facie presence or otherwise of any element of culpability on the part of such suspect. Third, in the event of there being no prima facie culpability established by investigation, any further proceedings may be dropped at the level of the Collector of Excise which is a quasi-judicial authority in this case. Fourth, prima facie establishment of culpability on the part of the suspect would change his status from 'suspect' to 'accused' in the wake of investigation and a detailed investigation report to that effect would have to be submitted by the investigating officer to the Judicial Magistrate so that judicial proceedings may be initiated subsequently in that regard. In the event of the allegations apparently established by investigation being substantiated in the court of law following a full-blown trial, the accused would be handed a sentence in accordance with the penal provisions laid down in the BE Act. And fifth, such investigation report which the officer submits to the Judicial Magistrate under Section 74(4) of the BE Act is to be treated as a Police Report under Section 190 of Criminal Procedure Code, 1973.

\subsection{Significance of Police Report in Terms of Criminal Procedure Code}

Section 2(r) of CrPC defines police report as a report forwarded by a police officer to a Magistrate under sub-section (2) of section 173 Criminal Procedure Code. This is a document of instrument on which the Magistrate can rely for taking cognizance of an offence. Section 190 of the Code provides: Subject to the provisions of this Chapter (XIV), any Magistrate of the first class, and any Magistrate of the second class specially empowered in this behalf [under sub-section (2)], may take cognizance of any offence:-

(a) Upon receiving a complaint of facts which constitute such offence;

(b) Upon a police report of such facts;

(c) Upon information received from any person other than a police officer, or upon his own knowledge, that such offence has been committed.

The sub-section (2) provides: The Chief Judicial Magistrate may empower any Magistrate of the second class to take cognizance under sub-section (1) of such offences as are within his competence to inquire or try.

Thus, we see that in terms of the code of criminal procedure, a Magistrate can take cognizance of an offence by way of paying regard to any of these three instruments listed in Section 190, i.e. a complaint, a police report or information received from a non-police official unless he proceed to do so suo-motu based on his own information. No such case has however taken place in West Bengal as yet when the Magistrate took cognizance of an offence under the BE Act otherwise than by way of acting upon a complaint or a police report.

\subsection{What is a Complaint Then in Terms of Code of Criminal Procedure?}

The section 2(d) of the code provides that a complaint means any allegation made orally or in writing to a Magistrate, with a view to his taking action under the code that some person, whether known or unknown, has committed an offence, but does not include a police report. The definition of complaint clearly distinguishes it from a police report which means a report of investigation made by a police officer. A complaint thus means a simple account of allegation brought against some person by a non-police official. 


\subsection{Does It Have Any Procedural Implications Depending on Whether the Magistrate Receives a Complaint or a Police Report?}

All cases under the BE Act are warrant cases in terms of definition of the term as it's provided in the Code of Criminal Procedure. And the code actually provides two distinctly different sets of procedure depending on whether it's to going to be trial proceedings instituted on the basis of police report or otherwise (Note-7).

In the cases where proceedings are instituted on the basis of police report, framing of charges follows straightaway the submission of such report. The Magistrate goes through the detailed investigation report propped up by all the supporting documents in a police report case and comes to a decision as to whether there is a prima facie case or not and accordingly proceeds further to frame the charges against which the accused would be tried in the court.

In the cases where proceedings are instituted otherwise than on the basis of police report, such framing of charge does not take place straightaway after submission of complaint or otherwise. The fundamental reason why the Magistrate does not proceed immediately with framing of charge in such a scenario is that he wants to be apprised of the prima facie case before any further judicial action is undertaken at his end. The code thus provides for recording of all pre-charge evidence in front of the Magistrate under Section 244 of Code of Criminal Procedure which provides that when in any warrant case instituted otherwise than on a police report, the accused appears or is brought before a Magistrate, the Magistrate shall proceed to hear the prosecution and take all such evidence as may be produced in support of the prosecution. In the police report cases however the Magistrate proceeds towards the charge-framing stage after going through the case diary of the investigating officer maintained under section $172 \mathrm{CrPC}$ along with all the statements of the prosecution witnesses including that of the detecting officer recorded by the investigating officer under section $161 \mathrm{CrPC}$.

Why does the code distinguish one set of cases from another? What might be the legislative intent?

The police report cases which are also otherwise known as charge-sheet cases or completion report cases reach the courts only after an exhaustive round of investigation done by a competent police officer. It is the mandate of legislature that investigation be done prior to such cases reaching the courts and it is also the mandate of legislature that determines as to police officers of what level should conduct such investigation and understandably, the legislative intent is satisfied on account of that. The Code of Criminal Procedure legitimizes whatever investigation is done at least to the extent required for the Magistrate to find a prima facie case to proceed unless he decide otherwise to discharge the accused, based on his appreciation of arguments submitted by the defense under section 239 CrPC (Note-8).

A completely different procedure is adopted in the cases instituted otherwise than on the basis of police reports, i.e. the Magistrate himself hears all the depositions made by the prosecution witnesses in the open court in presence of the accused before he decides whether there is any prima facie case against the accused. This is required for ensuring that none is prejudiced while he be tried for an offence within the scope and meaning of criminal jurisprudence. There are many government agencies without appropriate powers of criminal investigation vested on their officers, for example, erstwhile Sales Tax authorities. However, their officers too detect cases that call for criminal proceedings in terms of their respective laws and accordingly, they lodge complaints with the Magistrates. Those officers not being vested with powers of police investigation in terms of the provisions of $\mathrm{CrPC}$, the Magistrate is not in a position to proceed straightaway with charge-framing because he has to be satisfied first about a prima facie case being there made out against the accused.

The same reason holds ground when the Magistrate faces a situation envisaged in clause (c) of sub-section 1 of section $190 \mathrm{CrPC}$, i.e. where he can take cognizance of offence upon information received from any person other than a police officer, or upon his own knowledge, that such offence has been committed. A conjoint reading of this clause and the clause (a) of the same sub-section implies that any person other than a police officer as mentioned here would include a private person (Note-9) How can a Magistrate proceed straightaway with charge-framing against a person based upon an allegation made by a private person or more interestingly, relying upon his own knowledge about commission of an offence by him without an obvious risk of lack of transparency in that regard? The apparent conundrum is resolved in Section 191 whereby such a case where cognizance is sought to be taken in terms of clause (c) of sub-section 1 of section $190 \mathrm{CrPC}$ may be transferred for further proceedings to a different Magistrate, subject to submission by the accused. In that scenario too, the Magistrate cannot take cognizance of commission of the offence on the basis of his own investigation. The job of investigation even in such a case is ordinarily required to be done by Police (Note-10)

Thus, it emerges that the provision for recording pre-charge evidence has been there in respect of non-police report cases with a view to ensuring there be no executive bias against the accused. The Magistrate himself hears all the depositions of prosecution witnesses in presence of the accused and proceeds either to frame charge under Section 246 $\mathrm{CrPC}$ or discharge the accused under section 245 of the Code. And in police report cases, he does not go through the additional process of recording pre-charge evidence from the prosecution witnesses since he relies upon the account of 
investigation duly done by empowered police officials. The accused in this case has however an opportunity under section $239 \mathrm{CrPC}$ to rebut the proposed charge brought by the prosecution.

\subsection{Real Implication of Recording Pre-Charge Evidence in a Non-Police Report Case}

On an average, it takes a minimum of 10 years for complete disposal of a case booked by an Excise officer under BE Act, 1909 while it is almost half the time so taken for a case booked by Police under the same Act to be disposed of (Note-11). Why such a vast divergence in terms of time taken for disposal of cases, depending upon who happens to be the prosecuting agency despite that both the agencies apply the selfsame substantive law in their respective proceedings? Could this ever be the true legislative intent?

But first, let's look at the factors responsible for this huge time difference in respect of disposal of a case booked by an Excise officer under the BE Act vis-à-vis such a case booked thereunder by his Police counterpart.

The courts in West Bengal like anywhere else in India are clogged with cases and infrastructural paucities (K.Jayanth Krishnan, 2011). No magisterial court in West Bengal can afford to hear the same matter on more than two occasions in a year (Note-12). This is what most importantly explains the extra time taken for disposal of a case booked by an Excise officer under the BE Act. A police officer submits the investigation report under Section $173 \mathrm{CrPC}$ and thus, a case booked and investigated by a Police officer can sidestep the process of pre-charge evidence recording and gain considerably in terms of time taken for disposal. Not so a case investigated by an Excise officer!

Now, as regards our unanswered question, was this ever the true legislative intent? Understanding that in both the cases, i.e. whether it's investigated by Police or Excise, it's the State of West Bengal who presses the prosecution within the scope and meaning of the selfsame law of the Bengal Excise Act, doesn't it result in an unintended discrimination between the two likes? And in that case, does it not jeopardize the law of equality and thereby, the rule of law?

\section{Ut Res Magis Valeat Quam Pereat and Section 74(4) of the BE Act}

The jurisprudential maxim implies that it is better to validate a thing than to invalidate it. A statute is supposed to be an authentic repository of the legislative will and the function of a court is to interpret it in terms of that legislative intent. The court should as far as possible avoid a construction which would attribute irrationality to the Legislature. It must obviously prefer a construction which renders the statutory provision valid rather than that which would make it void (Note-13). The rule is well-settled that a construction which imputes to the Legislature tautology or superfluity in terms of use of language must be, as far as possible, avoided. The Court should always prefer a construction which will give some meaning and effect to the words used by the Legislature, rather than that which will reduce it to futility (Note-14). Thus, when a harmonious construction is possible which furthers the objects of the Act, the same is preferred to that which might lead to any conflict between the two possible propositions (Note-15) No part of the statute can just be ignored by saying that the Legislature enacted the same not knowing what it was saying. It is to be assumed that the Legislature deliberately used that expression and it intended to convey the same meaning (Note-16)

Now, coming to the Section 74(4) of the BE Act, it concludes that following the investigation undertaken "the investigating officer (...) shall submit a report, which shall for the purpose of Section 190 of the Code of Criminal Procedure, 1973 be deemed to be a police report..." The use of 'shall' as auxiliary verb in respect of a third person singular number subject (i.e. 'report') unfailingly conveys an element of compulsion and leaves no room whatsoever for any discretion to be exercised by the Magistrate as to whether to treat such report as a police report or otherwise. In other words, the Court must view such report of investigation submitted by the investigating officer under section 74(4) of the $\mathrm{BE}$ Act as a report defined vide section 2(r) of $\mathrm{CrPC}$, i.e. treated at par with the report submitted under sub-section (2) of section $173 \mathrm{CrPC}$.

Thus, in terms of the procedural mandate of the special law read with the provisions of criminal procedure code, there is simply no scope for recording pre-charge evidence under Section $244 \mathrm{CrPC}$ before proceeding towards charge-framing unlike in the non-police report cases.

Still the investigation reports submitted under section 74(4) of the BE Act, 1909 have always been treated as so-called 'complaints' and as a consequence, disposal of Excise cases under the BE Act, 1909 booked by Excise Officers has been witnessing an inordinate delay vis-à-vis the cases booked by Police and investigation reports submitted under sub-section (2) of section $173 \mathrm{CrPC}$. As a fall-out, the administration of justice suffers even as such an important procedural legal mandate has remained unimplemented. What could be the factors responsible for this?

\section{NDPS Act: Another Case Study in Legislation-Implementation Divide}

\subsection{Section 52A of NDPS Act and the Intent Behind}

The much criticized (Note-17) anti-narcotics law titled Narcotic Drugs \& Psychotropic Substances Act was promulgated in India in 1985 with an eye on putting massive curbs on all illicit supply channels of narcotic substances. The legislature 
turned out to be even more realistic when Section 52A was incorporated in 1989 (Note-18) and the very text of sub-Section (1) thereof is more than eloquent about the legislative intent of the amendment in question:

Section 52A: Disposal of seized narcotic drugs and psychotropic substances:

(1) The Central Government, may, having regard to the hazardous nature, vulnerability to theft, substitution, constraint of proper storage space or any other relevant consideration, in respect of any narcotic drugs, psychotropic substances, controlled substances or conveyances, by notification in the Official Gazette, specify such narcotic drugs, psychotropic substances, controlled substances or conveyance or class of narcotic drugs, class of psychotropic substances, class of controlled substances or conveyances, which shall, as soon as may be after their seizure, be disposed of by such officer and in such manner as that Government may, from time to time, determine after following the procedure hereinafter specified.

While the opening sub-section encapsulates the enabling provision for such disposal, the three subsequent sub-sections provide the detailed modality and the legislative sanctity of such modalities vis-à-vis the provisions of the Indian Evidence Act, 1872 and the Code of Criminal Procedure, 1973.

\subsection{Section 52A (2) Provides}

Where any narcotic drugs, psychotropic substances, controlled substances or conveyances has been seized and forwarded to the Officer-in-Charge of the nearest Police Station or to the Officer empowered under Section 53, the Officer referred to in sub-Section (1) shall prepare an inventory of such narcotic drugs, psychotropic substances, controlled substances or conveyances containing such details relating to their description, quality, quantity, mode of packing, marks, numbers or such other identifying particulars of the narcotic drugs, psychotropic substances, controlled substances or conveyances or the packing in which they are packed, country of origin and other particulars as the Officer referred to in sub-Section (1) may consider relevant to the identity of narcotic drugs, psychotropic substances, controlled substances or conveyances in any proceedings of this Act and make an application to any Magistrate for the purpose of:

(a) Certifying the correctness of the inventory so prepared; or

(b) Taking in the presence of such Magistrate, photographs of such drugs, psychotropic substances, controlled substances or conveyances and certifying such photographs as true; or

(c) Allowing to draw representative samples of such drugs or substances in the presence of such Magistrate and certifying the correctness of any list of samples so drawn.

Section 52A (3) provides that where an application is made under sub-section (2), the Magistrate shall, as soon as may be, allow the application while the sub-section (4) says that notwithstanding anything contained in the Indian Evidence Act, 1872 or the Code of Criminal Procedure, 1973, every Court trying an offence under this Act, shall treat the inventory, the photographs of narcotic drugs, psychotropic substances, controlled substances or conveyances and any list of samples drawn under sub-section (2) and certified by the Magistrate, as primary evidence in respect of such offence.

\subsection{Express Legislative Intent in Section $52 \mathrm{~A}$}

Let's try to understand the sententia legis involved here. The opening sub-Section sets out the context that deals with the compelling exigencies which might require the Government of India to bring out certain modalities sanctioned by legislation towards disposing of such seized substances much before conclusion of trial. After the Central Government brings it out, all other relevant stakeholders, i.e. the drug law enforcement officers effecting the seizure in sub-section (2), the Judicial Officer mentioned in sub-section (3) and the trying court mentioned in sub-section (4) are left with no scope for discretion but to act in the direction set out by the Central Govt. by way of such notification or Standing Order. The Central Govt. came out with such directives post this Section 52A for the first time in 1989 itself in the form of Standing Order 1/89 dated 13.06.1989.

Thus, it is the Central Govt. alone who had this discretion granted by the enabling provision vide sub-Section (1) of the Section 52A while the Judicial Officer mentioned in sub-Section (3) as well as such Officer meant vide sub-Section (4) were intended to have a compulsion to proceed in the direction envisaged therein. The very mention of the auxiliary verb shall on both the occasions says it all too clearly (Note-19)

But there is a mention of shall in sub-section (2) as well and there too it is used in regard to a third person singular number subject, i.e. the drug law enforcement officer. The ball is supposed to start rolling only after the drug law enforcement officer compulsorily approaches the judicial officer with his specific application asking for certification with an eye on disposal. 


\subsection{The Mohanlal Case \& Section $52 A$}

No law achieves its purpose if it's left unimplemented and the case of Union of India vs. Mohanlal \& Another unfailingly pointed out once again the shocking degree of non-application of this specific provision of the NDPS Act almost across the spectrum throughout the country. The Apex Court undertook a country wide exercise to study the level of implementation of this mandatory provision of the NDPS Act and the findings were shocking enough to galvanize the administrative machinery of the Apex Court.

Let's look at some of the observations of the Apex Court in connection with the Mohanlal case:

On 3rd July, 2012 this Court after hearing the Amicus Curiae prima facie came to the conclusion that the procedure prescribed for the destruction of the contraband seized in different States was not being followed resulting in a very piquant situation in which accumulation of huge quantities of the seized drugs and narcotics has increased manifold the chances of their pilferage for re-circulation in the market.

This Court also noted a report published in the timesofindia.indiatimes.com under the heading "Bathinda's police stores bursting at seams with seized narcotics" from which it appeared that large quantities of seized drugs had accumulated over the years including opium, poppy husk, charas etc. apart from modern narcotic substances. The report suggested that 39 lakhs sedatives and narcotic tablets, 1.10 lakhs capsules, over 21,000 drug syrups and 1828 sedative injections apart from 8 kgs. of smack and $84 \mathrm{kgs}$. of ganja were awaiting disposal in Bathinda Police stores alone.(Paragraph-2)

There is in our opinion no manner of doubt that the seizure of the contraband must be followed by an application for drawing of samples and certification as contemplated under the Act. There is equally no doubt that the process of making any such application and resultant sampling and certification cannot be left to the whims of the officers concerned. The scheme of the Act in general and Section 52A in particular, does not brook any delay in the matter of making of an application or the drawing of samples and certification. While we see no room for prescribing or reading a time frame into the provision, we are of the view that an application for sampling and certification ought to be made without undue delay and the Magistrate on receipt of any such application will be expected to attend to the application and do the needful, within a reasonable period and without any undue delay or procrastination as is mandated by sub-section (3) of Section 52A. We hope and trust that the High Courts will keep a close watch on the performance of the Magistrates in this regard and through the Magistrates on the agencies that are dealing with the menace of drugs which has taken alarming dimensions in this country partly because of the ineffective and lackadaisical enforcement of the laws and procedures and cavalier manner in which the agencies and at times Magistracy in this country addresses a problem of such serious dimensions.(Paragraph-14)

Following Mohanlal, all the High Courts in the country did swing into action. Special committees of Judges were formed in every High Court and Special Narcotics Judges took the initiative to physically inspect the storage places where the drug law enforcement agencies kept the seized narcotic alamats. Drug law enforcement agencies are almost regularly now presenting applications under Section 52A and the specially designated Magistrates are duly dealing with them.

But why did it take more than 26 long years and an unusual judgment from the Apex Court encompassing a pan-India exercise spanning over four years (Note-20) to put on track a serious piece of legislation already enacted by the Parliament of India?

\section{Lipsky's Theory \& the Case Studies in Divergence}

\subsection{Revisiting the BE Act Conundrum}

But let's try first to address the Bengal Excise riddle in terms of Lipsky's theory of street level bureaucracy. Why wasn't the import of Section 74(4) made use of with an eye on early disposal of court cases despite manifest legislative intent to that effect? We can find an answer in Lipsky's logic.

Despite anything and everything said to the contrary, State Excise in West Bengal primarily remains a revenue organization and thus mobilization of revenue has remained its principal initiative. No doubt, there are enforcement activities and consequent prosecution procedure when someone is caught cheating on this revenue objective but such enforcement activities occupy a miniscule importance in terms of organizational scheme of things (Note-21). Liquor after all is not banned in West Bengal and thus, enforcement activities there are more regulatory in nature than fundamentally geared towards policing. Officials too in West Bengal Excise are fundamentally revenue officials and thus, largely un-impacted by the protocol of a police organization in terms of functioning (Note-22). Going by the Lipsky logic, the existence of a provision like Section 74(4) in the scheme of Bengal Excise Act has not really gelled with the overall organizational objective. It's a singular provision cloaked in police language whereas the entire organization essentially functions along non-police lines. Thus, there remains a significant divergence from the overall organizational goal vis-à-vis this Section 74(4) of BE Act, which has put the implementation of this specific provision on the backburner, as it were. 
What is more, in absence of such generic objective to implement this specific provision of law, there have emerged other vested interests in favour of its non-implementation too. An investigating Excise Officer is required to do a lot less work when the investigation report is treated as a complaint. He can just report to the court, complaining against a specific person without going through all the rigours of investigation enjoined upon him in terms of Chapter XII of the Code of Criminal Procedure and leave the entire work of such investigation to be done by the Judicial Magistrate by way of inquiry. Defence lawyers are happy as well because this so-called complaint case procedure prolongs a case and thereby affords him a much better scope for earning by way of larger number of appearance opportunities (Note-23). The monopoly of service providers being the other reason forwarded by Lipsky to be behind non-implementation of laws also finds some substance on this point. The accused have to depend on his counsel and more or less all such defence counsels in the lower courts are driven by the same calculations. And the State prosecutors appearing in lower courts have absolutely no incentives whatsoever in ensuring any expeditious conclusion of proceedings because their performance assessment does not really hinge on such issues (Note-24). This too conforms very much to what Lipsky says in regard to performance assessment issues having an adverse impact on implementation of laws.

And going by the same Lipsky logic, it's probably only the Judicial Magistrates who should have an incentive to ensure early disposal of such cases since rate of disposal has a definitive bearing on their performance appraisal. West Bengal Judicial Academy has however already started going about it. (Note-25)

\subsection{Factors Behind Non-Implementation of Section 52A of NDPS Act}

How is it that organizations like Directorate of Revenue Intelligence (DRI) under Department of Revenue, Govt. of India or Narcotics Control Bureau (NCB) under Ministry of Home Affairs, Govt. of India or even Customs, etc almost religiously implemented the mandate of Section 52A of the NDPS Act while State Police organizations almost all over the country faltered as a matter of routine? Once again, we may turn to Lipsky. Organizations suffering from clarity of goal vis-à-vis a specific provision of law may often find themselves faltering in regard to implementation thereof. NDPS Act has quite a few stringent provisions which are often branded as draconian. Section 37 provides one such stringency. It mandates that no person accused of an offence punishable for offences under Section 19 or Section 24 or Section 27A and also for offences involving commercial quantity shall be released on bail or on his own bond unless...the Court is satisfied that there are reasonable grounds for believing that he is not guilty of such offence and that he is not likely to commit any offence while on bail. The sub-Section (2) further commands that the limitations on granting of bail specified ... are in addition to the limitations under the Code of Criminal Procedure or any other law for the time being in force, on granting of bail. It remains a kind of open secret that State Police organizations in India have had an unenviable track record of using this specific provision for a range of extra-anti-narcotic purposes. Even the Law Commission's $277^{\text {th }}$ Report on "Wrongful Prosecution (Miscarriage of Justice): Legal Remedies" is eloquent on how Police fabricates FIRs with an eye on ensuring denial of bail to someone for a considerable period of time. Provisions like Section 37 of NDPS Act provide an apparently easy opportunity to that effect. Officers in charge of Police stations often are compelled to clamp such charges on persons who they desperately endeavour to keep behind the bars for a certain period of time.

Keeping a ready stock of seized narcotic drugs in the police go-downs apparently comes in handy under such circumstances since a minimum of stipulated commercial quantity of narcotic drugs has to be presented by the seizing agency as the quantity of seized drugs every time someone is sent to the Court by the agency officials on drug charges. The pending stock of drugs understandably serves that purpose (Note-26). In other words, under such circumstances, Police doesn't exactly do what he is supposed to do as a Policeman and, there often remains a severe lack of clarity of purpose within the organization as to what he should do and how. The non-implementation of the Section 52A largely stems from there. Obviously, any such due compliance of the Section would put him in an unpredictably difficult situation!

No such predicament however confronts an NCB official or his counterpart in Customs or DRI since NCB, DRI or Customs are not required to handle law-and-order situations that are more often than not punctuated with sharp political overtones. These non-police agency officials thus know what they do and are aware of why they do what they do. Organizational goal or the lack thereof hardly makes them confront situations laden with any unwholesome potential of holding them back from implementation of this piece of legislation.

\section{Conclusion}

The Apex Court has cracked the Mohanlal whip no doubt. But it would be an interesting study none the less to see how an organization like State Police pits itself against the demands of due procedure of Section 52A of the NDPS Act in view of the principal challenges confronted by the agency and its men in this regard. Whether the judicial directive from the highest level will be honored in its entirety or diluted beyond redemption will definitely remain something to watch out for.

As regards the issue exposed in regard to the Bengal Excise Act, it might be still difficult on the part of agency officials to do full justice to the import of Section 74(4) of the Bengal Excise Act given the fact that the agency would always remain primarily a revenue organization provided West Bengal does not embrace prohibition as a state policy. The agency will 
always have an intrinsic force to remain auto-directed more towards the issues related to revenue mobilization and far less towards compliance of rules of criminal procedure in the court of law. On the other hand, it would be interesting to see how the sensitization of the judicial officers in the State undertaken by the Judicial Academy can go to leave a more meaningful impact on such compliance. After all, it is the courts alone that stand to benefit from such compliance in this case.

\section{Endnotes}

1. Note-1: For example, the Indian Penal Code lists out the offences and defines them while the Code of Criminal Procedure provides the mechanism as to what exactly has to be done by a criminal law enforcement official following detection of an offence and apprehension of an offender and even afterwards, how the entire issue must be addressed and disposed of by a judicial officer. There are also certain enactments which contain a broadly self-sufficient framework providing both the substantive and the procedural parts subject however to the overarching mandate of the general law.

2. Note-2: The procedural parts do go an equally long way in translating the legislative intent into reality. They spell out for the relevant actors as to how to do what the substantive law wants them to do.

3. Note-3: Its preamble sets out the agenda: "An Act to consolidate and amend the Excise law in Bengal. Whereas it is expedient to consolidate and amend the law in Bengal relating to the export, import, transport, manufacture, possession and sale of intoxicants..."

4. Note-4: This however excludes potable alcohol imported from outside of India and sold afterwards within the State. Such articles attract Customs duty imposed by the Government of India while the State Government does levy certain fees on that.

5. Note-5: See chapters III, IV \& V of the Bengal Excise Act, 1909 http://wbexcise.gov.in/writereaddata/bengalexciseact.pdf

6. Note-6: Section 67 of the Bengal Excise Act read with Section 81 thereof and Chapter V of Code of Criminal Procedure, 1973. http://legislative.gov.in/sites/default/files/A1974-02.pdf

7. Note-7: While Part A of CrPC, Chapter XIX provides the procedure of trial of warrant cases instituted on the basis of a police report, Part-B thereof provides the trial procedure of cases instituted otherwise than on the basis of police report. http://legislative.gov.in/sites/default/files/A1974-02.pdf

8. Note-8: Section 239 of the Criminal Procedure Code provides this.

9. Note-9: Surrendro Nath Roy (1870) 13 WR (Cr) 27

10. Note-10: K. Shankaraiah vs. State of AP, 1983 CrLJ (1296) AP

11. Note-11: This is based on the author's inspection of data of court cases maintained in Excise units all over West Bengal. There are even cases which have been running for close to 25 years in courts of judicial magistrates and not yet disposed of!

12. Note-12: In fact, such is the enormous workload at the courts that often there are occasions when the Magistrate gets to hear only once during an entire year. Thus, supposing there being on an average eight or ten officials on the part of the prosecution, it takes a minimum of five or six years to complete the process of pre-charge evidence recording. This is in addition to multiple other factors responsible for delay, such as, absence of the accused on the day of evidence, adjournments moved by the prosecution, absence of prosecution witnesses for recording of such evidence once they get transferred out of the district where the detection took place, etc.

13. Note-13: K.P. Varghese v. ITO[1981] 131 ITR 597 (SC); State of Punjab v. Prem Sukhdas [1977] 3 SCR 40314. Note-14: CIT v. R.M. Amin [1977] 106 ITR 368 (SC); Addl. CIT v. Surat Art Silk Cloth Mfrs. Association [1980] 121 ITR 1 (SC)

15. Note-15: CWT v. Yuvraj Amrinder Singh [1985] 156 ITR 525 (SC)

16. Note-16: CIT v. Distributors (Baroda) (P.) Ltd.[1972] 83 ITR 377 (SC)

17. Note-17: NDPS Act remains one of the worst criticized laws in India on account of its stringent measures including its framework of graded penal structure and virtual absence of judicial discretion in regard to grant of bail in favor of the accused.

18. Note-18: This was further amended in 2014 and seized controlled substances and conveyances were included as articles meriting such disposal.

19. Note-19: The exclusion of auxiliary verbs like may or will and use of shall for a third person singular subject like 'magistrate' or 'court' clearly envisages there is no scope for discretion to be exercised by the magistrate in 
sub-Section (3) in regard to whether he should allow such an application; or in sub-Section (4) whether such photographs and other records duly certified should be allowed to be treated as primary evidence notwithstanding the provisions contained in The Evidence Act, 1872. The national legislature has thus thrust a compulsion on the judicial officers in this regard.

20. Note-20: The exercise continued from 2012 till 2016

21. Note-21: A completely different scenario emerges in a prohibition State like Bihar or Nagaland, etc where the entire organizational goal in Excise is geared towards policing.

22. Note-22: The revenue entity of Excise officials was also officially endorsed when Excise ceased to exist as a separate Department and Excise Directorate became one of the Directorates under Department of Finance in 2018. Supervisory officers too became part of West Bengal Revenue Service.

23. Note-23: Excise offenders come out on bail all too easily, unlike drug offenders and thus, the defence lawyers are hardly under any obligation to see these cases come to any early conclusion. Complaint case procedure suits them very well.

24. Note-24: Theirs is a service which does not hold out any prospects of promotion. An Assistant Public Prosecutor who is appointed by the Government to present cases for the State in the JM courts does not get to become a Public Prosecutor at the District Judge's Court by promotion. Someone who is selected as an Assistant Public Prosecutor gets to retire as an Assistant Public Prosecutor.

25. Note-25: West Bengal Judicial Academy has already started addressing this issue. Judicial Magistrates are being duly sensitized about such provisions of law and how exactly the same may be duly leveraged.

26. Note-26: There are reports that State Police agencies almost everywhere in the country do resort to clamping false narcotic cases for multiple reasons. The reports about Punjab or Tamilnadu are only symptomatic of the larger malaise.

https://www.hindustantimes.com/cities/five-ludhiana-cops-convicted-of-framing-man-in-false-case/story-TYMUH BkDjM5kAPDE7qtZ2N.html \& https://www.indiatoday.in/magazine/states/story/20010730-chennai-police-alleged-to-have-used-narcotics-to-settle -political-scores-773898-2001-07-30

\section{References}

Milward, B. (1980). Policy Entrepreneurship and Bureaucratic Demand Creation. In H. I. Mann. Why Policies Succeed or Fail (pp. 255-277). Beverley Hills, California: SAGE.

D. Mazmanian, P. S. (1983). Implementation and Public Policy. Glenville: Scott Foresman.

Dye, T. R. (1972). Understanding Public Policy. Prentice Hall.

K. Jayanth Krishnan, C. R. (2011). Delay in Process, Denial of Justice: The Jurisprudence and Empirics of Speedy Trials in Comparative Perspective. Indiana.

Matland, R. (1995). Synthesizing the Implementation Literature:Ambiguity Conflict Model of Implementation. Journal $f$ Public Administration Resach and Theory, 145-174.

\section{Copyrights}

Copyright for this article is retained by the author(s), with first publication rights granted to the journal.

This is an open-access article distributed under the terms and conditions of the Creative Commons Attribution license which permits unrestricted use, distribution, and reproduction in any medium, provided the original work is properly cited. 